\title{
Delignification of Date Palm Fronds using Modified Organosolv Technique
}

\author{
Yasmeen Salih Mahdi* \\ Asem Hassan Mohammed** \\ Alaa Kareem Mohammed*** \\ *, ***Department of Biochemical Engineering / Al-Khwarizmi Engineering College / University of Baghdad \\ **Institute of Technology Baghdad/Chemical Industries/Middle Technical University \\ *Email: yasmeensalih90@ gmail.com \\ **Email: asemh2005@yahoo.com \\ ***Email: alaauniv@yahoo.com
}

(Received 2 July 2017; accepted 18 July 2017)

https://doi.org/10.22153/kej.2017.07.001

\begin{abstract}
In this study, modified organic solvent (organosolv) method was applied to remove high lignin content in the date palm fronds (type Al-Zahdi) which was taken from the Iraqi gardens. In modified organosolv, lignocellulosic material is fractionated into its constituents (lignin, cellulose and hemicellulose). In this process, solvent (organic)-water is brought into contact with the lignocellulosic biomass at high temperature, using stainless steel reactor (digester). Therefor; most of hemicellulose will remove from the biomass, while the solid residue (mainly cellulose) can be used in various industrial fields. Three variables were studied in this process: temperature, ratio of ethanol to water and digestion time. Statistical experimental design type Central Composite Design (CCD) has been used to find a mathematical relationship between the variables and the remaining lignin percent as dependent variable. The results obtained in this study were represented by a polynomial mathematical equation of the second degree. The results showed that the best digestion time was ( 80 minutes), which gave the best percent remaining concentration of lignin $(3 \%)$ at temperature of $185^{\circ} \mathrm{C}$ and ratio of ethanol: water equal to $50: 50 \mathrm{wt} / \mathrm{wt}$. In order to reduce digesting time, the effect of using different catalysts have been studied such as $\left(\mathrm{NaOH}, \mathrm{H}_{2} \mathrm{SO}_{4}, \mathrm{Ca}(\mathrm{OH})_{2}\right)$ at low concentration $(0.025,0.025,0.05 \mathrm{M})$ respectively. It was found that the best catalyst is sodium hydroxide at concentration $(0.025) \mathrm{mol} / \mathrm{L}$ which gave the same percent of lignin $3 \%$ but with low digestion time about $30 \mathrm{~min}$.
\end{abstract}

Keywords: Biomass pre-treatment, delignification, lignin, organosolv, date palm fronds.

\section{Introduction}

Delignification is removal of lignin from woody tissue as by natural enzymatic or industrial chemical processes so that it can be used for applications like making Rayon or making paper [1]. Lignin is an organic substance binding the cells, fibers and vessels which constitute wood and the lignified elements of plants, as in straw. It is the most abundant renewable carbon source on Earth [2]. There are several methods concerning delignification. Kraft process is one of these methods [3], which is capable to remove about $95 \%$ of lignin from woody biomass. In this method, the wood chips are digesting at high pressure and elevated temperature in the existence of whit liquor (solution of sodium hydroxide and sodium sulfide). This process is carried out either batch or continuous in a bioreactor that called digester [4]. Another method is oxygen delignification, which is a process between cooking and bleaching sequences, where part of the residual lignin left in pulp after cooking is removed using oxygen and alkali[5]. The targeted reactions are the oxidation of lignin and breaking it down parts which dissolve in alkali, as well as destroying the colored groups in lignin and removal of impurities, such as resin. Oxygen 
delignification is not so efficient as Kraft method, it removes only $55 \%$ of lignin [6]. It is, however, often used as a supplementary tandem process to the more traditional Kraft method. Delignification using microorganisms was also investigated. In production of bioethanol from plant material, removal of lignin using microbial reaction was used simultaneously with conversion of cellulose to bioethanol at low level of temperature [7]. Scientist also try to change the content and structure of lignin by microorganisms in order to either improve its digestibility to animals [7] or to increase the utility of the cell walls for biofuel production paper manufacturing [8]. Another technique of delignification is organosolv process which involves contacting a lignocellulosic feedstock such as chipped wood with an aqueous organic solvent at temperatures ranging from 150 to $220{ }^{\circ} \mathrm{C}$ [9]. Solvents used include acetone, methanol, butanol, ethylene glycol, formic acid, and acetic acid. The concentration of solvent in water ranges from 20 to $80 \%$ [10]. Organosolv has several advantages when compared to other popular methods such as Kraft or sulfite pulping since it has the ability to obtain relatively high quality lignin [4]. Organosolv solvents are easily recovered by distillation, leading to less water pollution and elimination of the odor usually associated with Kraft pulping[11]. The purpose of the current study is delignification of date palm fronds in order to remove about $95 \%$ of its lignin content using modified organosolv technique.

\section{Experimental Work}

\subsection{Materials and Methods}

\subsubsection{Composition analysis of data palm fronds}

The date palm fronds samples were collected from Babylon garden from one kind of date palm (Al-Zahdi) and stored in pre- sterilized bags in refrigerator freeze. The Samples then transferred to the laboratory for testing and before being treated, impurities were removed by washing them with distilled water for several times .After that the samples were shredded using electric cutter and crushed with humor then sieved. Fragments with particle size of (90-270) $\mu \mathrm{m}$ were selected for the steps of analysis. The composition of date palm fronds (leaves and stalk) were determined according to National Renewable Energy Laboratory (NREL) LAPs for compositional analysis [12]. Table (1) shows the composition of fronds (leaves and stalk).

Table 1,

The composition of date palm fronds (leaves and stalk) based on dry weight Wt \%

\begin{tabular}{llllll}
\hline Sample & Carbohydrate & lignin & Ash & Extractive & Protein \\
\hline Leaves & 52 & 27 & 8 & 10 & 4 \\
stalks & 59 & 23 & 7 & 8 & 3 \\
\hline
\end{tabular}

\subsubsection{Preparation of Ethanol Solution}

Solutions of ethanol were prepared with different ratios of ethanol: water. They are: (20:80, 33:67, 50:50, 67: 33 and 80:20 wt/wt). 200 $\mathrm{ml}$ of each solution was prepared. For example to prepare $200 \mathrm{ml}$ solution with ratio ethanol: water of 20:80, $41.666 \mathrm{~g}$ of ethanol (96\% concentration) is completed to $200 \mathrm{ml}$ with distilled water. In the same way, the other solutions were prepared by completing appropriate amount of ethanol to 200 $\mathrm{ml}$ with distilled water.

\subsubsection{Description of the Reactor}

Two liter stainless steel reactor was used in this study with $11 \mathrm{~cm}$ in diameter and $21 \mathrm{~cm}$ length. The reactor was heated from the side through a jacket-type heater, while heated from bottom by magnetic stirrer hot plate as shown in Figure (1). The reactor was provided with a thermocouple equipped with temperature controller to control the temperature inside the reactor. The pressure inside the reactor was indicated using pressure gauge. 

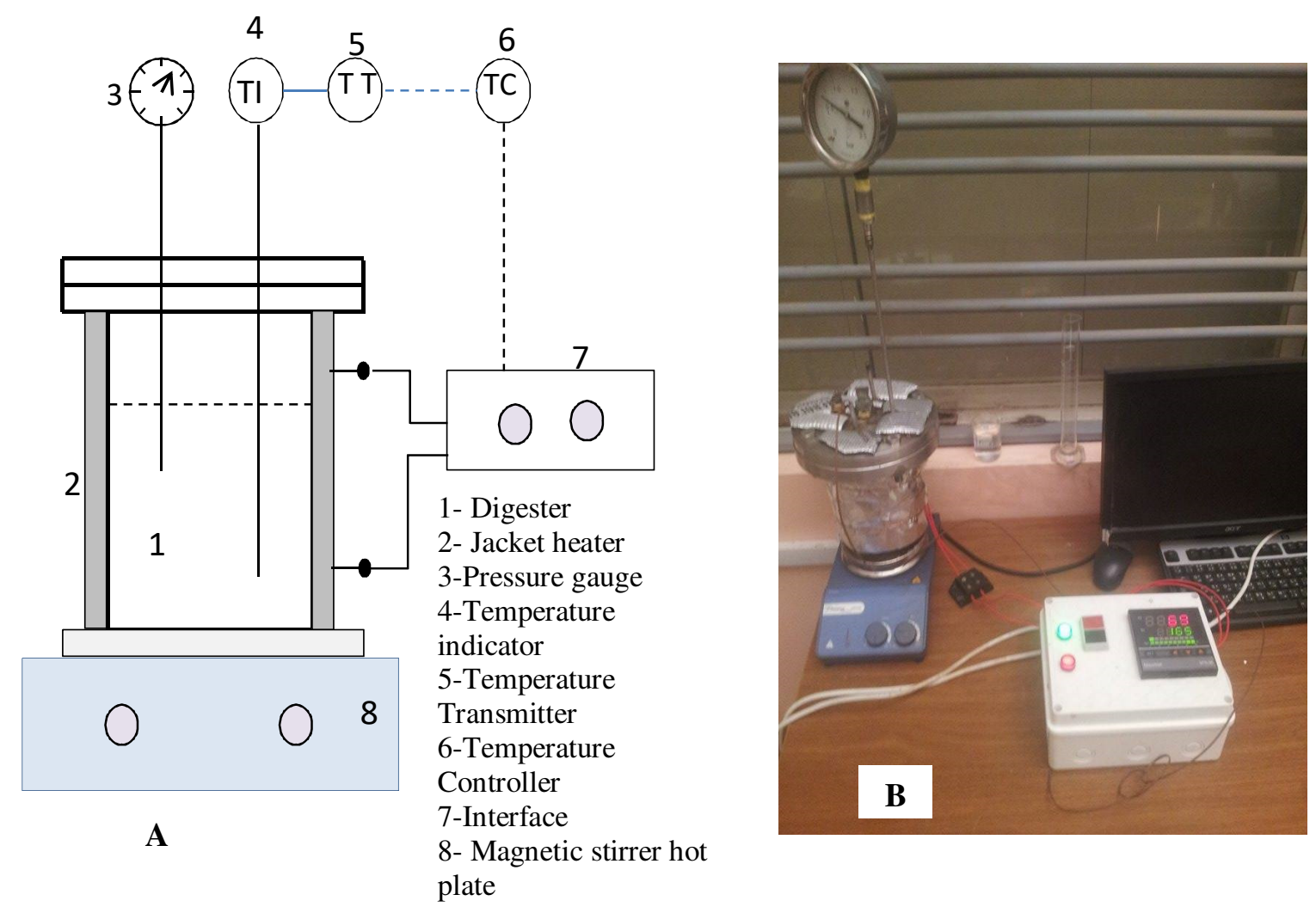

8- Magnetic stirrer hot
plate

Fig. 1. A: Schematic Diagram of the reactor. B: The reactor and its components which used in experiments.

\subsubsection{Procedure}

Lab scale experiments were performed in two liter autoclave batch reactor. The date palm fronds (biomass) were milled to about $0.18 \mathrm{~mm}$. A suspension of biomass-water-organic solvent (ethanol) was made (typically, $200 \mathrm{ml}$ solvent per $20 \mathrm{~g}$ biomass). The effect of ethanol solvent is to hydrolysed lignin in the sample but has no effect on cellulose[13]. In some experiments, catalyst was added. This suspension was heated to a specific reaction temperature (in the range 150 $200^{\circ} \mathrm{C}$ ) while being stirred. This suspension then kept at its set point during a certain reaction time (typically, $60 \mathrm{~min}$ ) and subsequently cooled down. After filtration of the resulting slurry, the solid residue was washed with an identical organic solvent-water mixture and dried at $105^{\circ} \mathrm{C}$. From the filtrate solution, samples were taken for UV analysis.

\subsubsection{Washing and filtration of the sample after delignification}

After the run completed, the treated sample was washed with ethanol /water solution( 80:20, ethanol: water) and then with distilled water for several times until the color of liquor change from brown color to colorless, then the solution was filtered using vacuum pump as shown in the Figure ( 2 ). 


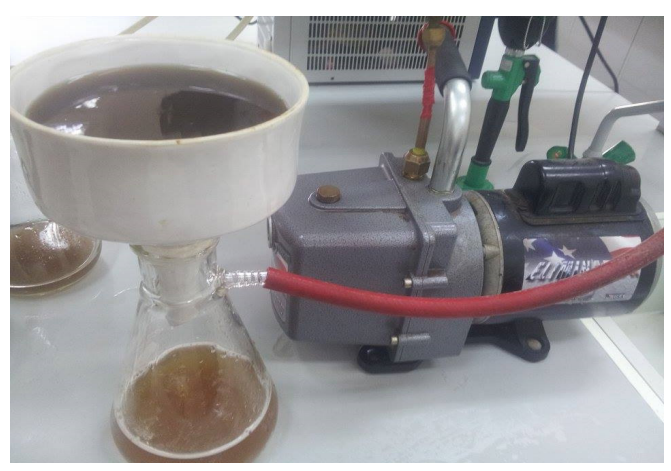

Fig. 2. Vacuum pump for washing and filtration process.

\subsubsection{Bleaching}

Bleaching is a chemical processing carried out on various types of wood pulp to remove the color of the pulp, so that it becomes whiter. The goal of bleaching chemical pulps is to remove essentially all of the residual lignin; hence the process is often referred to as delignification[4]. Chlorine is the basis for the most common bleaching process. Three grams of dried sample was weighted and put into $500 \mathrm{ml}$ flask, then $250 \mathrm{ml}$ of sodium chlorite solution $(60 \mathrm{~g} / \mathrm{l}$ sodium chlorite and $60 \mathrm{~g} / \mathrm{l}$ sodium acetate) was added, the sample was soaked for four days[14]. Then it was washed with distilled water for several times, followed by extraction with $0.15 \mathrm{~N} \mathrm{NaOH}$ twice and then washed with hypochlorite and distilled water thoroughly. Finally, the sample was freeze-dried. It was note that the color was changed from dark brown to white as show in the Figure (3).

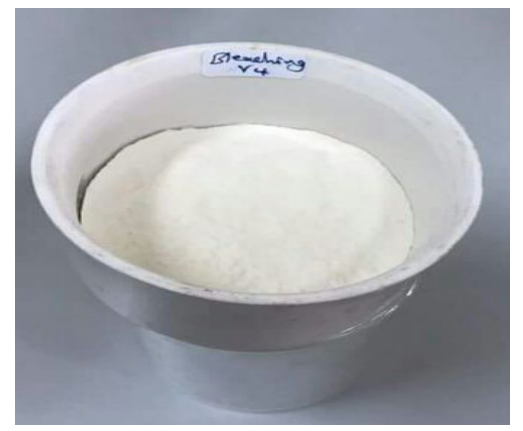

Fig. 3. The sample after bleaching.

\subsubsection{Lignin Content}

The lignin content was determined according to the renewable energy laboratory standard procedure[15], $0.3 \mathrm{~g}$ of date palm frond with particle size less than $180 \mu \mathrm{m}$ was put into a dried test tube and then $3 \mathrm{ml}$ of $\mathrm{H}_{2} \mathrm{SO}_{4} 72 \%$ was added to it. The tube was placed in water bath at $30^{\circ} \mathrm{C}$ for $1 \mathrm{hr}$ then the sample mixed with $84 \mathrm{ml}$ distilled water in glass bottle and placed in autoclave for 1 $\mathrm{hr}$ at $125^{\circ} \mathrm{C}$. Then the sample filtered with weighed crucible using vacuum pump. Two types of lignin were obtained, lignin acid soluble and lignin acid insoluble. The weight percent of lignin acid insoluble residue (AIR) can be calculated by eq. (1).

$$
\begin{aligned}
& \% \text { AIR = } \\
& \frac{\text { Weight }_{\text {crucible plus AIR }}-\text { Weight }_{\text {crucible }}}{\text { ODW }_{\text {sample }}} * 100
\end{aligned}
$$

ODW: oven dry weight which can be calculated using equation (2).

$\mathrm{ODW}=$
Weight $_{\text {sample befor dried }}-$ Weight $_{\text {sample after dried }}$
Weight $_{\text {sample befor dried }}$

Two milliliter of liquor was diluted with $4 \mathrm{ml}$ distilled water in dried test tube ,then the(UVabs) absorbance was measured at wave length $320 \mathrm{~nm}$ [16].

The amount of acid soluble lignin (ASL) can be calculated using equation (3)

$\% \mathrm{ASL}=$
$\frac{\mathrm{UV} \text { abs } * \text { Volume }_{\text {filtrate }} * \text { Dilution }}{\varepsilon * \text { ODW }_{\text {sample }} * \text { Pathlength }} * 100$

Where:

Volume of filtrate was taken $=86.73 \mathrm{~mL}$

$\varepsilon=$ Absorptivity of biomass at specific wavelength equal to (11.4)[6]

Path length = path length of UV-Vis cell in $\mathrm{cm}$ $(1 \mathrm{~cm})$

Dilution can be calculated using equation (4)

Dilution

$$
=\frac{\text { volume }_{\text {sample }}+\text { volume }_{\text {diluting solvent }}}{\text { volume }}
$$

The total amount of lignin can be calculated using equation (5).

$\%$ lignin $=\%$ AIR $+\%$ AS

\section{Results and Discussion}

Three parameters have been studied (temperature, ethanol/water ratio and time) with respectively ranges $(150-220) \mathrm{C}^{\mathrm{o}},(20-80) \mathrm{Wt} . \%$, (20-80) min. Seventeen experiments were conducted in this study with parameters values were selected according to the statistical 
experimental design type (CCD). The

experimental values were shown in Table (2).

Table 2,

Effect of experimental parameters on lignin percent.

\begin{tabular}{lllll}
\hline Runs & Temperature, ${ }^{\mathbf{0}} \mathbf{C}$ & $\begin{array}{l}\text { Ratio } \\
\text { Ethanol :water }\end{array}$ & Time, min & $\begin{array}{l}\text { Lignin \% } \\
\text { content }\end{array}$ \\
\hline 1 & 185.00 & 50.00 & 80.00 & 3 \\
2 & 150.00 & 50.00 & 50.00 & 9 \\
3 & 205.21 & 67.32 & 67.32 & 5.5 \\
4 & 164.79 & 67.32 & 32.68 & 12.5 \\
5 & 185.00 & 50.00 & 50.00 & 6 \\
6 & 185.00 & 80.00 & 50.00 & 8 \\
7 & 220.00 & 50.00 & 50.00 & 5.5 \\
8 & 185.00 & 20.00 & 50.00 & 10 \\
9 & 164.79 & 32.68 & 32.68 & 11.5 \\
10 & 164.79 & 67.32 & 67.32 & 6.8 \\
11 & 185.00 & 50.00 & 20.00 & 6 \\
12 & 164.79 & 32.68 & 67.32 & 6.2 \\
13 & 185.00 & 50.00 & 50.00 & 8 \\
14 & 205.21 & 32.68 & 32.68 & 7.5 \\
15 & 205.21 & 32.68 & 67.32 & 6.3 \\
16 & 185.00 & 50.00 & 50.00 & 6.5 \\
17 & 205.21 & 67.32 & 32.68 & \\
\hline
\end{tabular}

\subsection{Mathematical Model}

In the experimental work, the values of independent variables, which were temperature, ethanol: water ratio and digesting time, were selected according to Central Composite Design (CCD). Design of experiments (DOE) program using Central response technique has been used to find a mathematical relationship between the three dependent variables and the independent variable which is the remaining lignin percent in the sample. A second - order polynomial correlation was obtained as shown in eq.(6).

$$
\begin{aligned}
y=B_{0}+B_{1} x_{1} & +B_{2} x_{2}+B_{3} x_{3}+B_{4} x_{1} x_{2} \\
& +B_{5} x_{1} x_{3}+B_{6} x_{2} x_{3}+B_{7 x_{1}^{2}} \\
& +B_{8} x_{2}^{2}+B_{9} x_{3}^{2}
\end{aligned}
$$

Where

B0, B1, B2...B9 are coefficients of Polynomial equation.

$\mathrm{X}_{1}, \mathrm{X}_{2}$ and $\mathrm{X}_{3}$ are the real variables $\left(\mathrm{X}_{1}\right.$ :

temperature, $\mathrm{X}_{2}$ : ethanol/water ratio, $\mathrm{X}_{3}$ : Time)

$\mathrm{y}$ is the remaining lignin percent

\subsection{Estimation the Coefficients of the Second Order Equation}

The coefficients of equation (6) can be determined by using computer software (Design Expert) so equation (6) can be written as follow:

$$
\begin{aligned}
& y=6.17-1.10 X_{1}-0.37 X_{2}-1.53 X_{3}-0.66 X_{1} X_{2} \\
& +1.21 X_{1} X_{3}-0.088 X_{2} X_{3} \\
& \quad+0.51 X_{1}^{2}+1.09 X_{2}^{2}-0.072 X_{3}^{2}
\end{aligned}
$$

Correlation coefficient $=0.9681$

Relative standard deviation $=3.6 \%$

\subsection{Effect of Temperature and Ethanol/Water Ratio on Lignin Content}

According to the mathematical model of eq. (6) the effects of temperature and ethanol/water ratio were studied at certain value of time. Figure (4) shows the contours of lignin percent content at different values of temperature and ethanol/water at constant time 20 min. Minimum value of lignin percent contained was $6.89 \%$ which obtained at a lowest temperature of $191^{\circ} \mathrm{C}$ and solvent ratio (ethanol: water equal to 50:50 wt/wt). Decreasing the temperature below $191^{\circ} \mathrm{C}$ will led to increase the value of lignin\% content in the sample. This is because decreasing the temperature will prevent full fractional of lignocellulosic material and then the lignin percent will be increase at temperature below $180^{\circ} \mathrm{C}$. 


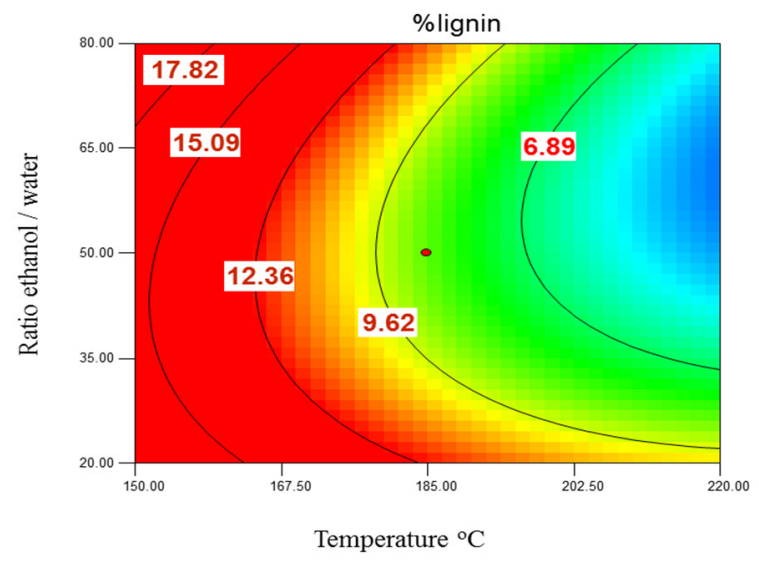

Fig. 4. Effect of temperature and ethanol/ water ratio on lignin percent at constant time $20 \mathrm{~min}$.

Figure (5) shows the effect of temperature and ethanol/water ratio on lignin percent content at constant time $50 \mathrm{~min}$. The best lignin percent lie on contour $6.11 \%$ which was obtained at lowest temperature $185^{\circ} \mathrm{C}$ and ethanol: water ratio at 50:50. On comparison with figure (4) at constant time $20 \mathrm{~min}$, it can be concluded that increasing digestion time leads to decrease the temperature as well as improve the removal of lignin. Although increasing temperature will lead to decrease the lignin content, but it is not recommended to exceed the digestion temperature above $185^{\circ} \mathrm{C}$ because many changes will happen to the cellulose structure and destroy it[17].

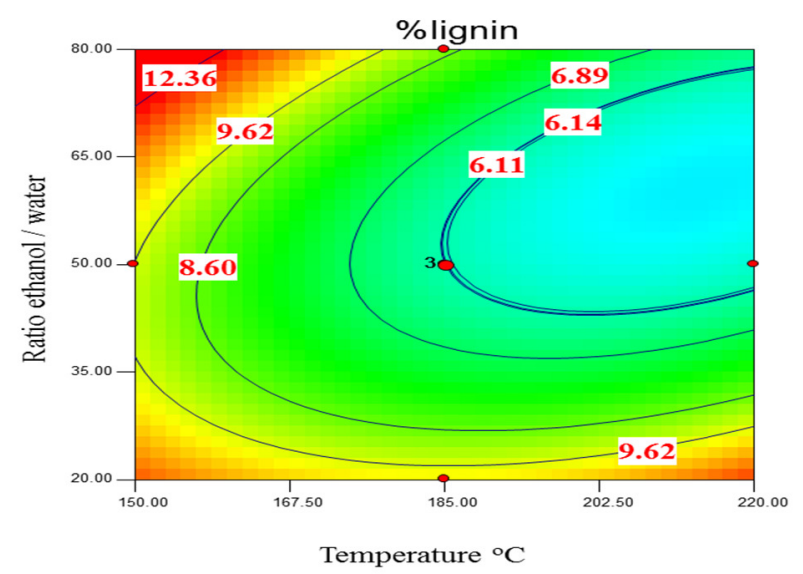

Fig. 5. Effect of temperature and ratio on lignin percent at constant time 50 min.

Figure (6) shows that best lignin percent content $(3.08 \%)$ was obtained when use digestion time $80 \mathrm{~min}$ at temperature is $185^{\circ} \mathrm{C}$ and solvent ratio of 50:50. So this is the optimum operating condition for lignin removal.

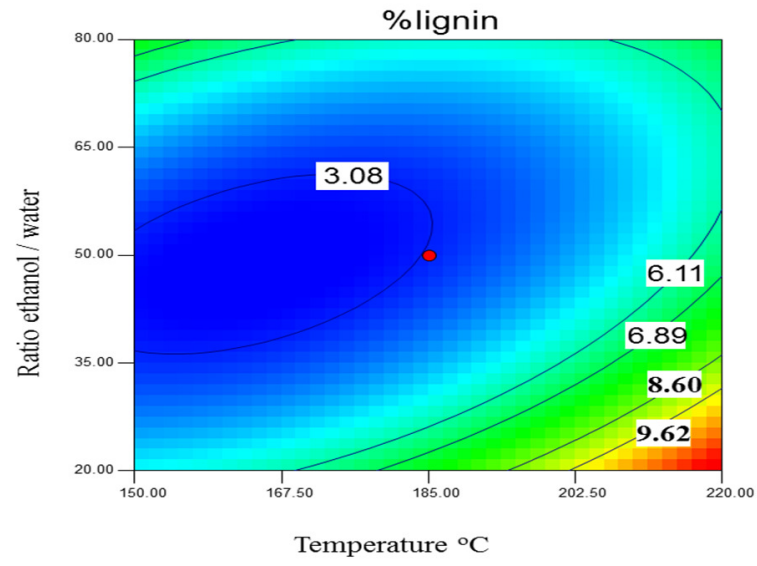

Fig. 6. (Effect of temperature and ratio on lignin percent at constant time 80 min).

\subsection{Effect of using Catalyst}

As it has been shown from the above context, the time of digestion is very important parameter in the delignification process and time $80 \mathrm{~min}$ gave perfect lignin percent content, but this time is too long therefore; a possibility to improve the organosolv process might be the application of a catalyst. In the literature, $\mathrm{H}_{2} \mathrm{SO}_{4}, \mathrm{NaOH}$ and $\mathrm{Ca}$ $(\mathrm{OH})_{2}$ are a well-known catalysts for biomass pretreatment processes [9]. Catalysts were used with concentration of $0.025 \mathrm{M}$ for each of $\mathrm{H}_{2} \mathrm{SO}_{4}$ and $\mathrm{NaOH}$ and $0.05 \mathrm{M}$ for $\mathrm{Ca}(\mathrm{OH})_{2}$. The experiments were conducted at $180^{\circ} \mathrm{C}$ and ratio of ethanol: water equal to 50:50. Figure (7) shows that the treated sample without catalysts gave 3\% lignin content and $80 \mathrm{~min}$ digestion time, while all catalysts reduced the digestion time to $30 \mathrm{~min}$, but lignin percent content was minimum $(3 \%)$ when using $\mathrm{NaOH}$. Other catalysts gave higher lignin content as shown in figure (7). So it can be concluded that among the catalysts used in the experiments sodium hydroxide was the most efficient in reducing time of digestion while keeping the lignin content at minimum value. On the other hand sodium hydroxide has another benefit. It is working on reducing the degree of polymerization of remains sample (mainly cellulose) and this is important in the subsequent steps in the process of synthesis of rayon [18]. 


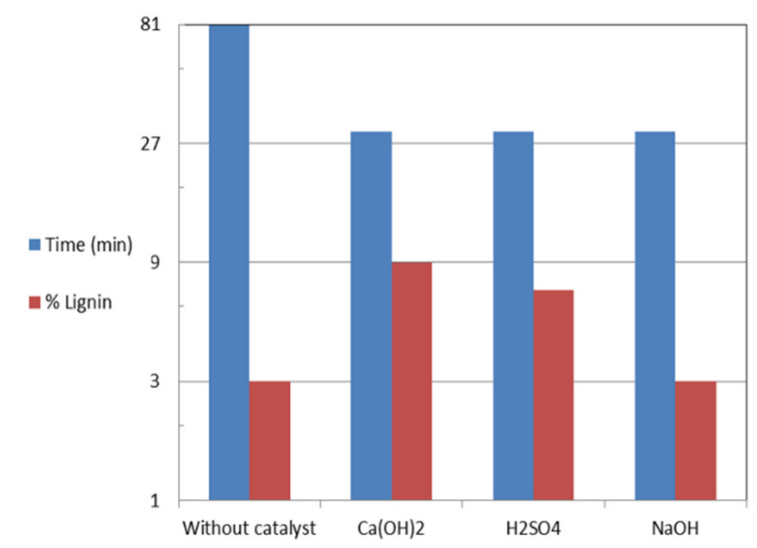

Fig. 7. Effect of different catalysts on lignin percentage content. Conditions are $185^{\circ} \mathrm{C}$, and ratio ethanol: water $=\mathbf{5 0 : 5 0}$.

\section{Conclusion}

Based upon the results obtained so far, there is a possibility to dignify the date palm fronds using modified organosolv. The more effective parameters in the delignification process were: temperature, ethanol/ water ratio and time.

Without catalyst, the optimum conditions for delignification process were: temperature $185^{\circ} \mathrm{C}$, ethanol: water 50:50 and digestion time $80 \mathrm{~min}$. In order to reduce the digestion time, three types of catalysts were tested: $\mathrm{H}_{2} \mathrm{SO}_{4}, \mathrm{NaOH}$ and $\mathrm{Ca}(\mathrm{OH})$ 2. Among them, sodium hydroxide $(0.025 \mathrm{M})$ was found the best one which reduces the time from $80 \mathrm{~min}$ to $30 \mathrm{~min}$.

\section{References}

[1] V. Chain, E. Ec, D. G. Energy, E. Let, E. Have, E. Consultation, B. Era, N. E. T. Cofund, I. Agenda, E. E. Commission, E. Strategy, E. Oecd, and F. A. O. A. Outlook, "Pretreatment of biomass for conversion to advanced biofuels Pretreatment of biomass to facilitate conversion to bioenergy or biofuels Overview Latest News Energy densification Organosolv process," pp. 1-2, 2013.

[2] Y. Wang, "Cellulose fiber dissolution in sodium hydroxide solution at low temperature: Dissolution kinetics and solubility improvement," p. 133, 2008.

[3] H. Tran and E. K. Vakkilainnen, "The Kraft Chemical Recovery Process," TAPPI Kraft Recover. Course, pp. 1-8, 2012.

[4] R. Fornell, Process integration studies on Kraft pulp-mill- based biorefineries producing ethanol. 2012.

[5] A. H. Mohammed, "Conversion of lignocellulosic material into Fermentable sugars," no. September, p. 131, 2012.

[6] K. Zhang, Z. Pei, and D. Wang, "Organic solvent pretreatment of lignocellulosic biomass for biofuels and biochemicals: A review," Bioresour. Technol., vol. 199, pp. 21-33, 2016.

[7] R. Singh, A. Shukla, S. Tiwari, and M. Srivastava, "A review on delignification of lignocellulosic biomass for enhancement of ethanol production potential," Renew. Sustain. Energy Rev., vol. 32, pp. 713-728, 2014.

[8] L. Mesa, E. González, C. Cara, M. González, E. Castro, and S. I. Mussatto, "The effect of organosolv pretreatment variables on enzymatic hydrolysis of sugarcane bagasse," Chem. Eng. J., vol. 168, no. 3, pp. 11571162, 2011.

[9] W. J. J. Huijgen, R. R. den Laan, and J. H. Reith, "Modified organosolv as a fractionation process of lignocellulosic biomass for co-production of fuels and chemicals," 16th Eur. Biomass Conf. Exibition, Spain, no. June, pp. 2-6, 2008.

[10] P. J. Kleppe, "Kraft Pulping," Tappi, vol. 53, no. 1, pp. 35-47, 1970.

[11] D. Chiaramonti, M. Prussi, S. Ferrero, L. Oriani, P. Ottonello, P. Torre, and F. Cherchi, "Review of pretreatment processes for lignocellulosic ethanol production, and development of an innovative method," Biomass and Bioenergy, vol. 46, pp. 25-35, 2012.

[12] B. Hames, R. Ruiz, C. Scarlata, a Sluiter, J. Sluiter, and D. Templeton, "Preparation of Samples for Compositional Analysis Laboratory Analytical Procedure ( LAP ) Issue Date: 8 / 06 / 2008 Preparation of Samples for Compositional Analysis Laboratory Analytical Procedure ( LAP )," Natl. Renew. Energy Lab., no. August, pp. 19, 2008.

[13] P. Kumar, D. M. Barrett, M. J. Delwiche, and P. Stroeve, "Methods for pretreatment of lignocellulosic biomass for efficient hydrolysis and biofuel production," Ind. Eng. Chem. Res., vol. 48, no. 8, pp. 3713-3729, 2009.

[14] C. Linters Studying the Improvement of the Solubility of Cellulosic Fibers," vol. 22, no. 7, pp. 21-37, 2016.

[15] A. Sluiter, B. Hames, R. Ruiz, C. Scarlata, J. Sluiter, D. Templeton, and D. C. Nrel, 
"Determination of Structural Carbohydrates and Lignin in Biomass Determination of Structural Carbohydrates and Lignin in Biomass," vol. 2011, no. April 2008, 2012.

[16] R. Sierra, M. T. Holtzapple, and C. B. Granda, "Long-term lime pretreatment of poplar wood," AIChE J., vol. 57, no. 5, pp. 1320-1328, 2011.

[17] S. E. Zayed, A. B. A. Adam, E. A. Hassan, and M. A. El-kady, "Renewable Egyptian lignocellulosic materials as alternative raw material for particleboard manufacturing," vol. 18 , no. 2 , pp. 262-272, 2015.

[18] N. Mosier, C. Wyman, B. Dale, R. Elander, Y. Y. Lee, M. Holtzapple, and M. Ladisch, "Features of promising technologies for pretreatment of lignocellulosic biomass," Bioresour. Technol., vol. 96, no. 6, pp. 673686, 2005. 


\title{
ازالة اللكنين من سعف نخيل التمربأستخدام طريقة المذيب العضوي المعدله
}

\author{
ياسمين صالح مهدي* * عاصم حسن محمد** علاء كريم محمد

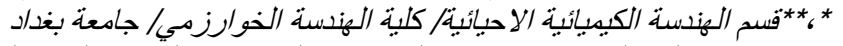

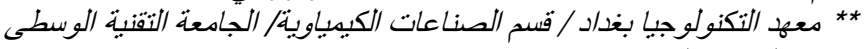

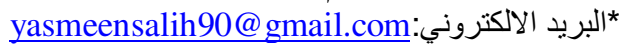

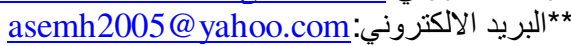

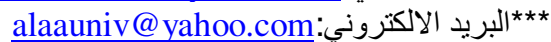

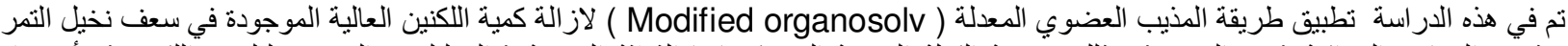

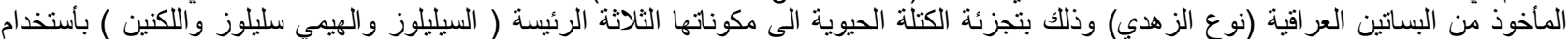

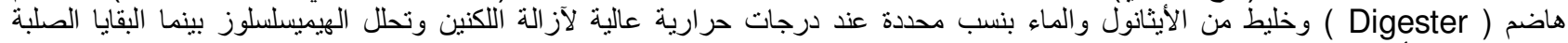
(السيليلوز) يتم أذابته في العمليات اللاحقة لآستخدامه في مجالات صنات صناعية مختلفة. نم دراسة ثلاثة متغير ات الات في هذه العملية وهي : درجة الحرارة و نسبة الايثانول الى الماء و الوقت.

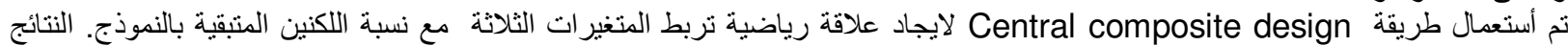

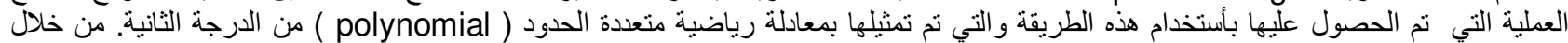

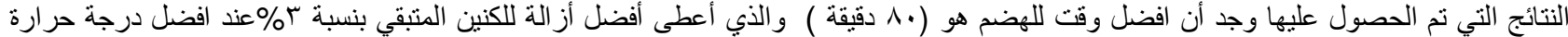

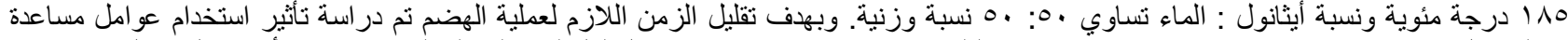
مختلفة منل (NaOH , Ca(OH)2, H2SO

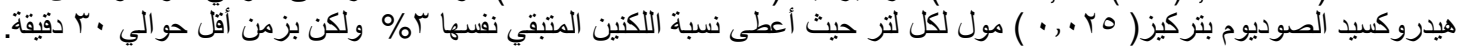

